\title{
Effects of Four Anesthetics, Clove Extract, Thyme Extract, Lidocaine, and Sodium Bicarbonate on the Blood Parameters and Cortisol Amount in Grass Carp (Ctenopharyngodon Idella)
}

\author{
Effati Masoumeh', Bahrekazemi Masoumeh"*
}

*Corresponding author: Bahrekazemi Masoumeh, Department of Fisheries, Qaemshahr Branch, Azad University, Qaemshahr, Iran. Tel: +989383450086/Fax:+981142155117. E-mail: bahr.kazemi@gmail.com

\begin{abstract}
The anesthetic effects of two chemical compounds, lidocaine and sodium bicarbonate, and two natural compounds, clove and thyme extracts, were examined on the Red Blood Cells (RBC), White Blood Cells (WBC), hemoglobin, hematocrit, and blood cortisol levels of Grass carp at two times of 10 minutes and 24 hours after anesthesia. RBC counts had no significant increase in the samples of $10 \mathrm{~min}$ and $24 \mathrm{~h}$ after induction of anesthesia with clove extract only compared to the control group $(\mathrm{p}>0.05)$. The number of WBC increased significantly in the samples from 10 min and $24 \mathrm{~h}$ after anesthesia with sodium bicarbonate only and it was not different from control samples in other treatments $24 \mathrm{~h}$ after anesthesia. The amount of hemoglobin indicated an increase with all treatments compared to the control in $10 \mathrm{~min}$ after anesthesia. The increases were not significant in thyme and clove extract $(\mathrm{P}>0.05)$. Samples treated at $24 \mathrm{~h}$ after anesthesia exhibited non statistical hemoglobin elevations with thyme extract only. Hematocrit increased significantly in the samples from 10 min after anesthesia with lidocaine and sodium bicarbonate but, at $24 \mathrm{~h}$ after anesthesia, hematocrit amount with thyme and clove extracts and lidocaine treatments were not different from the control significantly $(\mathrm{P}>0.05)$. Also, Cortisol level was significantly higher in both sampling times for lidocaine and sodium bicarbonate treatments than the control group. Accordingly, the use of natural anesthetics (thyme and clove extracts) will result in better outcomes than the synthetic compounds (sodium bicarbonate and lidocaine) in the Grass carp.
\end{abstract}

Received date: June 23, 2017

Accepted date: February 01, 2017

Published date: February 06, 2017

Citation: Masoumeh, B., et al. Effects of Four Anesthetics, Clove Extract, Thyme Extract, Lidocaine, and Sodium Bicarbonate on the Blood Parameters and Cortisol Amount in Grass Carp (Ctenopharyngodon Idella). (2018) J Marine Biol Aquacult 4(1): 1- 4.

Keywords: Anesthetics; Clove Extract; Grass Carp; Sodium Bicarbonate; Thyme Extract

Copy Rights: (C) 2018 Masoumeh, B. This is an Open access article distributed under the terms of Creative Commons Attribution 4.0 International License.

DOI: $10.15436 / 2381-0750.18 .1586$

\section{Introduction}

In today's aquaculture industry of many countries, anesthesia techniques receive special attention to reduce stress and achieve higher meat quality.The use of anesthetics and stolidity drugs in aquaculture can positively impact the quality of protein produced ${ }^{[1]}$. The main purposes of anesthetizing fish include reducing mobility and stress in operations such as tagging, biometrics, sorting, examination, and sampling ${ }^{[2]}$. A compound for use as an anesthetic in aquaculture should have three features of safety, cheapness, and availability ${ }^{[3]}$. The impact of an anesthetic on fish depends on many factors such as, its concentration, water temperature, fish size, and the species ${ }^{[4]}$. Common anesthetics in aquaculture include tricaine methane sulfonate (MS222), benzocaine, coinaldine, metomidate, clove extract, and 2-phenoxy eth- ano ${ }^{[5]}$. Some of these anesthetics have carcinogenic effects and, in addition, the periods of avoidance for human consumption are sometimes very long in the health legislations of countries ${ }^{[6]}$. Furthermore, some of the compounds (e.g.MS222) currently used as anesthetics in the aquaculture industry are very expensive.

So far, a number of studies have been carried out in order to assess and describe the physiological effects of various anesthetics on aquaculture species ${ }^{[7-9]}$. Hormonal and humoral analyses are methods of assessing the effects of anesthetic drugs. During and/or following anesthesia, the blood of fish may undergo some transient or prolonged changes. These changes can include anemia, compensatory increase in $\mathrm{RBC}$, increased WBC count, and changes in blood cortisol levels caused by oxygen deficiency, and stress among other factors ${ }^{[5]}$. The aim of this study, 
Citation: Masoumeh, B., et al. Effects of Four Anesthetics, Clove Extract, Thyme Extract, Lidocaine, and Sodium Bicarbonate on the Blood Parameters and Cortisol Amount in Grass Carp (Ctenopharyngodon Idella). (2018) J Marine Biol Aquacult 4(1): 1- 4 .

therefore, was to evaluate the effects of anesthetic combination of herbs (thyme and clove extracts) and two chemical anesthetics (lidocaine and sodium bicarbonate) on the Grass carp.

\section{Materials and Methods}

This research was carried out in a warm-water fish farm located in Sari, northern Iran. A total of 48 Grass carp with an average weight of $200 \mathrm{~g}$ and length of $18 \mathrm{~cm}$ were randomly divided into five groups. All the water conditions of the tanks (such as temperature, oxygen content, $\mathrm{pH}$, etc.) were controlled and kept at optimal levels during the experimental period Table1.

Table 1. Conditions of water during the study period

\begin{tabular}{|l|c|c|}
\hline Parameter & Value & Optimal range \\
\hline Water temperature $\left({ }^{\circ} \mathrm{C}\right)$ & $21-23$ & $25-17$ \\
\hline $\mathrm{pH}$ & 7.7 & $6.5-8$ \\
\hline Ammonia $(\mathrm{mg} / \mathrm{l})$ & 0.6 & $0-0.02$ \\
\hline Nitrite $(\mathrm{mg} / \mathrm{l})$ & 0.0 & $0-0.1$ \\
\hline Total hardness $(\mathrm{mg} / \mathrm{l})$ & 285 & $10-400$ \\
\hline Dissolved oxygen $(\mathrm{mg} / \mathrm{l})$ & 8 & $5-10$ \\
\hline
\end{tabular}

Lidocaine (2\%) was obtained from the Pasteur Institute of Iran, sodium bicarbonate from Soda Kaveh Chemical Industry Co., and clove and thyme extracts from Giah Essence Pharmaceutical Co. To prepare the anesthetic solutions, an amount of each anesthetic was added to the water container [Table 2], and then the resultant solution was completely stirred and homogenized. The fish were not fed $24 \mathrm{~h}$ prior to the start of the anesthetic trials. After preparing the anesthetic solutions with the desired concentrations [Table 2], fish were anesthetized via bathing in small tanks and then transferred to larger tanks to recover from anesthesia.

Table 2. The doses of anesthetics used in the current study3-16-23

\begin{tabular}{|l|c|c|c|}
\hline Anesthetic & $\begin{array}{l}\text { Recommended } \\
\text { dose }\end{array}$ & $\begin{array}{l}\text { An e st he sia } \\
\text { time (min) }\end{array}$ & $\begin{array}{l}\text { Recovery } \\
\text { time (min) }\end{array}$ \\
\hline Lidocaine & $150 \mathrm{mg} / 1$ & 2 & 5 \\
\hline Sodium bicarbonate & $300 \mathrm{mg} / 1$ & 5 & 10 \\
\hline Clove extract & $50 \mathrm{mg} / 1$ & 5 & 5 \\
\hline Thyme extract & $100 \mathrm{mg} / 1$ & 6 & 6 \\
\hline
\end{tabular}

Blood samples were taken from the caudal vein in two steps (10 min and $24 \mathrm{~h}$ after recovery of fish). Five blood samples were taken from five fish of each treatment as replications. A portion of the blood was transferred to non-heparinized tubes to measure cortisol hormone, and another fraction was poured into heparinized tubes for counting blood cells ${ }^{[10]}$. Blood samples were also taken from the control fish that had received no anesthetic. WBC and RBC number were counted manually using neubauer hemocytometer ${ }^{[11]}$. Hematocrit amount was measured according to microhematocrit method ${ }^{[12]}$. Hemoglobin amount was determined using a kit and spectrophotometry at $540 \mathrm{~nm}^{[13]}$, and cortisol level in blood was measured by radioimmunoassay

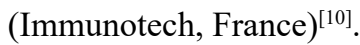

The statistical model used in this study was a completely randomized design. Within such a design, four anesthetics (clove and thyme extracts, lidocaine, and sodium bicarbonate) and a control group were studied as treatments each with five replications. Data were analyzed using SPSS version 21 at a confidence level of $95 \%$. The difference between means of the data were evaluated by the Analysis of Variance (ANOVA) and compared with Duncan's test.

\section{Results}

The results of this study showed that the numbers of RBC were not significantly different in the samples anesthetized by clove extract compared to control samples after $10 \mathrm{~min}$ and $24 \mathrm{~h}$ after anesthesia $(\mathrm{p}>0.05)$. The increases of RBC numbers in the other treatments were significant at both sampling times ( $p$ $<0.05$ ) Table 3.

Table 3. Comparison of differences in the studied blood parameters at different treatments

\begin{tabular}{|l|l|l|l|l|l|}
\hline & & $\begin{array}{l}\text { Red blood } \\
\text { cell }\left(\mathrm{N} \times 10^{6} /\right. \\
\left.\mathrm{mm}^{3}\right)\end{array}$ & $\begin{array}{l}\text { White } \\
\text { blood cell } \\
\left(\mathrm{N} / \mathrm{mm}^{3}\right)\end{array}$ & $\begin{array}{l}\text { Hemo- } \\
\text { globin } \\
(\mathrm{g} / \mathrm{dl})\end{array}$ & $\begin{array}{l}\text { Hemato- } \\
\text { crit }(\%)\end{array}$ \\
\hline Control & & $2.08 \pm 0.28^{\mathrm{a}}$ & $\begin{array}{l}3350 \pm \\
525.99^{\mathrm{a}}\end{array}$ & $\begin{array}{l}6.32 \pm \\
0.62^{\mathrm{b}}\end{array}$ & $\begin{array}{l}24.75 \pm \\
1.26^{\mathrm{a}}\end{array}$ \\
\hline Thyme & $10 \mathrm{~min}$. & $2.67 \pm 0.52^{\mathrm{bc}}$ & $\begin{array}{l}5100 \pm \\
476.48^{\mathrm{ab}}\end{array}$ & $\begin{array}{l}6.82 \pm \\
0.82^{\mathrm{bc}}\end{array}$ & $\begin{array}{l}28.00 \pm \\
2.45^{\mathrm{abc}}\end{array}$ \\
\hline extract & $24 \mathrm{~h}$ & $2.68 \pm 0.37^{\mathrm{bc}}$ & $\begin{array}{l}4075 \pm \\
675.15^{\mathrm{a}}\end{array}$ & $\begin{array}{l}7.65 \pm \\
0.80^{\mathrm{c}}\end{array}$ & $\begin{array}{l}27.50 \pm \\
2.38^{\mathrm{abc}}\end{array}$ \\
\hline Clove & $10 \mathrm{~min}$. & $2.43 \pm$ & $\begin{array}{l}5400 \pm \\
370.83^{\mathrm{ab}}\end{array}$ & $\begin{array}{l}6.92 \pm \\
0.46^{\mathrm{bc}}\end{array}$ & $\begin{array}{l}28.75 \pm \\
1.89^{\mathrm{abc}}\end{array}$ \\
\hline extract & $24 \mathrm{~h}$ & $2.26 \pm 0.25^{\mathrm{ab}}$ & $\begin{array}{l}5200 \pm \\
219.61^{\mathrm{ab}}\end{array}$ & $\begin{array}{l}6.65 \pm \\
0.89^{\mathrm{bc}}\end{array}$ & $\begin{array}{l}27.25 \pm \\
2.22^{\mathrm{ab}}\end{array}$ \\
\hline $\begin{array}{l}\text { Lido- } \\
\text { caine }\end{array}$ & $10 \mathrm{~min}$. & $2.71 \pm 0.53^{\mathrm{c}}$ & $\begin{array}{l}6075 \pm \\
955.12^{\mathrm{ab}}\end{array}$ & $\begin{array}{l}7.57 \pm \\
0.87^{\mathrm{c}}\end{array}$ & $\begin{array}{l}31.75 \pm \\
3.40^{\mathrm{c}}\end{array}$ \\
\hline & $24 \mathrm{~h}$ & $2.80 \pm 0.19^{\mathrm{c}}$ & $\begin{array}{l}5375 \pm \\
269.18^{\mathrm{ab}}\end{array}$ & $\begin{array}{l}5.17 \pm \\
0.76^{\mathrm{a}}\end{array}$ & $\begin{array}{l}27.50 \pm \\
1.73^{\mathrm{abc}}\end{array}$ \\
\hline Sodium & $10 \mathrm{~min}$. & $2.88 \pm 0.18^{\mathrm{c}}$ & $\begin{array}{l}7300 \pm \\
675.82^{\mathrm{c}}\end{array}$ & $\begin{array}{l}7.60 \pm \\
0.29^{\mathrm{c}}\end{array}$ & $\begin{array}{l}30.50 \pm \\
4.72^{\mathrm{bc}}\end{array}$ \\
\hline $\begin{array}{l} \\
\text { bicar- } \\
\text { bonate }\end{array}$ & $24 \mathrm{~h}$ & $2.62 \pm 0.19^{\mathrm{bc}}$ & $\begin{array}{l}6100 \pm \\
509.96^{\mathrm{b}}\end{array}$ & $\begin{array}{l}8.77 \pm \\
0.80^{\mathrm{d}}\end{array}$ & $\begin{array}{l}31.25 \pm \\
1.70^{\mathrm{bc}}\end{array}$ \\
\hline
\end{tabular}

*Values with the same letters in each column show no significant differences $(\mathrm{P}>0.05)$.

The number of WBC elevated 10 min after anesthesia with thyme extract, clove extract, and lidocaine compared to the control $\left(3350 \pm 525.99 \mathrm{~N} / \mathrm{mm}^{3}\right)$, these elevations were not significant $(\mathrm{P}>0.05)$. On the other hand,a statistical increase was observed $10 \mathrm{~min}$ and $24 \mathrm{~h}$ after anesthesia with sodium bicarbonate $(\mathrm{P}<0.05)$. Sampling in $24 \mathrm{~h}$ after anesthesia with the other treatments displayed no significant differences compare to the control group $(\mathrm{P}>0.05)$ Table 3.

The amount of hemoglobin in the control group was $6.32 \pm 0.62 \mathrm{~g} / \mathrm{dl}$. This indicated an increased with all treatment groups compared to the control in $10 \mathrm{~min}$ after anesthesia. The increases were not significant in thyme and clove extract $(\mathrm{P}>$ $0.05)$. Samples treated at $24 \mathrm{~h}$ after anesthesia exhibited non statistical hemoglobin elevations with thyme extract only. The results showed that hematocrit increased significantly in the samples from 10 min after anesthesia with lidocaine and sodium bicarbonate in relation to control. The amounts of hematocrit in samples belonged to $24 \mathrm{~h}$ after anesthesia with thyme and clove 
extracts and lidocaine treatments were not different from the control significantly $(\mathrm{P}>0.05)$.

In this study, the lowest amount of cortisol was measured in the blood of fish in the control group $(17.75 \pm 3.70 \mathrm{ng} /$ $\left.\mathrm{mm}^{3}\right)$. The amount of this hormone showed significant rises in the treatments of $10 \mathrm{~min}$ after anesthesia with lidocaine (38.05 $\pm 10.96)$ and sodium bicarbonate $(31.55 \pm 10.23)$ compared to the control group $(\mathrm{p}<0.05)$. Cortisol values displayed non-significant higher concentrations in the samples from $10 \mathrm{~min}$ after anesthesia with thyme $(19.75 \pm 2.36)$ and clove $(22.37 \pm 2.88)$ extracts. The fish anesthetized with lidocaine and sodium bicarbonate showed significant greater amounts of this hormone than the control samples $24 \mathrm{~h}$ after anesthesia [Figure 1].

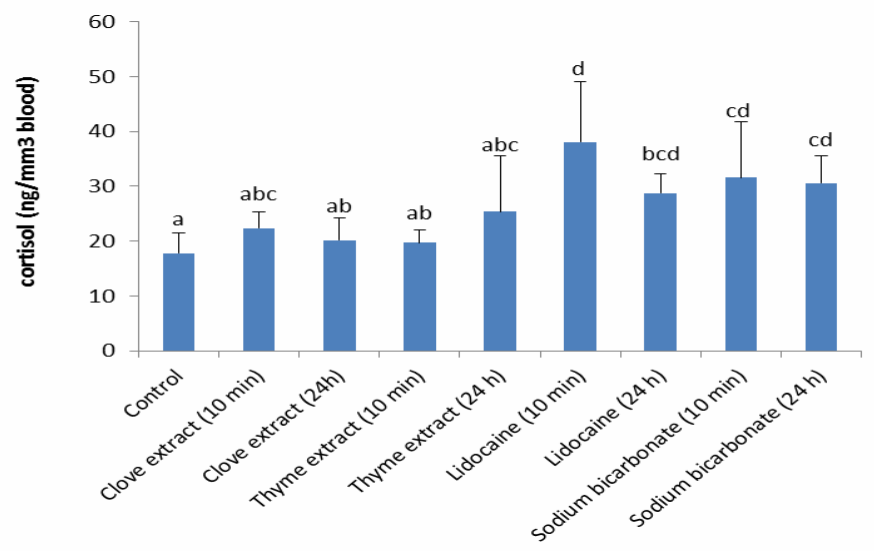

Figure1: Comparison of the cortisol hormone levels in the blood of Grass carps exposed to different anesthesia treatments.

\section{Discussion}

Since different species of fish show very different responses to anesthetic substances, determination of the type and dosage of such materials for any species often seems necessary. Analysis of blood parameters is one of the most important and reliable methods that can provide important information about an organisms healthy conditions ${ }^{[9]}$.

RBC counts, hemoglobin, and hematocrit changes are in relation to stressful environmental factors ${ }^{[14]}$. For example, increased number of RBCs indicates high stress levels in fish. The number of RBC, and levels of hemoglobin and hematocrit will change according to the species, gender, age of the fish, and stress factors ${ }^{[15]}$. In this study, the numbers of RBC were not significantly different in the samples anesthetized by clove extract only, after $10 \mathrm{~min}$ and $24 \mathrm{~h}$ after anesthesia. Research showed that the use of clove oil in the cat fish (Silurus glanis) could not cause any significant difference in the number of $\mathrm{RBC}^{[16]}$. The similar result was seen in the roach (Rutilus rutilus) ${ }^{[17]}$.

Stress can cause the number of white blood cells to rise. This occurs because the immune system is designed to kick into action to manage or prevent disease. When feeling stressed, the brain receives signals that there is a problem that needs to be addressed. The brain and the body of fish are in constant communication with one another. During times when stress is acute or short term, the brain can first respond to help the body deal with the situation. When the stressful event has ended the brain then sends signals to reverse the initial stress reaction, allowing the white blood cell count to return to normal ${ }^{[18]}$. The results of WBC count showed that only sodium bicarbonate treatment exhibited a marked increase $10 \mathrm{~min}$ and $24 \mathrm{~h}$ after anesthesia. Researchers examined anesthesia with clove oil in cat fish (Silurus glanis L.) and observed no significant different WBC count after $10 \mathrm{~min}$ and $24 \mathrm{~h}$ of anesthesia ${ }^{[16]}$ which is consistent with the results of the present study. The results of studies on the roach (Rutilus rutilus) ${ }^{[17]}$ and also on the Persian sturgeon (Acipenser persicus) ${ }^{[19]}$ revealed significant WBC elevations after 10 min anesthesia with clove extract, even so, no considerable differences from the control were detected following $24 \mathrm{~h}$ post-anesthesia contrary to the results of this study.

The incidence of stressful conditions results in an increase in the number of RBCs per unit of blood volume and, consequently, an increase in hemoglobin ${ }^{[14]}$. Lack of oxygen is a factor in a rapid increase of hemoglobin level and other main blood components ${ }^{[18]}$. In this study, the amount of hemoglobin in fish anesthetized with lidocaine and sodium bicarbonate showed significant increase after 10 min compared to the control group. Clove extract resulted insignificant rise in hemoglobin measures of $24 \mathrm{~h}$ of anesthesia compared to the control group. A study showed no significant differences in hemoglobin amount in catfish anesthetized with clove oil after $10 \mathrm{~min}$ and $24 \mathrm{~h}$ of anesthesia ${ }^{[16]}$ which is similar to the results of this study. The results of other studies on the roach ${ }^{[17]}$ and Persian sturgeon ${ }^{[19]}$ showed significant decreases in hemoglobin after $10 \mathrm{~min}$ of anesthesia with clove extract contrasting the findings of the present study.

The results from hematocrit analyses showed the significant increase in the samples from $10 \mathrm{~min}$ after anesthesia with lidocaine and sodium bicarbonate and in samples belonged to $24 \mathrm{~h}$ after anesthesia with sodium bicarbonate only. At study which used clove extract as an anesthetic for the broodstock of silver pond fish (Carassius gibelio) caused no significant changes in hematocrit values match with the results of this study in the clove extract treatment ${ }^{[20]}$. Similar to the results of the present study in fish treated with lidocaine, boosted RBC, WBC, hemoglobin, and hematocrit amounts were seen after exposure of gold fish (Carassius auratus auratus) to the lidocaine ${ }^{[21]}$.

Cortisol is known as the most important indicator of stress in animals. In this study, the amount of cortisol in the blood of fish showed a significant increase after anesthesia with lidocaine and sodium bicarbonate compared to the control group. Research showed decreased cortisol levels in the blood of rainbow trout (Oncorhynchus mykiss) treated with clove oil indicating diminished stressful conditions ${ }^{[22]}$. Also, the study of effects of clove extract on the channel catfish (Ictalurus punctatus), found it very effective in suppressing the secretion of cortisol hormone in the fish ${ }^{[23]}$, which corroborate the results of this study about the herbal anesthetics (thyme and clove extracts). The discrepancies between the results of different studies may be due to differences in species, gender, age, size, conditions of the culture media, the type and dose of the anesthetics, the anesthesia technique applied, and so on ${ }^{[24]}$.

\section{Conclusion}

It can be concluded that the use of natural compounds (extracts of thyme and clove) will yield better results in the grass carp in comparison with synthetic substances (sodium bicarbonate and lidocaine). 
Citation: Masoumeh, B., et al. Effects of Four Anesthetics, Clove Extract, Thyme Extract, Lidocaine, and Sodium Bicarbonate on the Blood Parameters and Cortisol Amount in Grass Carp (Ctenopharyngodon Idella). (2018) J Marine Biol Aquacult 4(1): 1- 4

\section{References}

1. Digre, H., Erikson, U., Skaret, J., et al. Biochemical, physical and sensory quality of ice-stored Atlantic cod (Gadus morhua) as affected by pre-slaughter stress, percussion stunning and AQUI-S ${ }^{\mathrm{TM}}$ anaesthesia. (2011) Eur Food Res Technol 233: 447-456.

Pubmed | Crossref | Others

2. Stoelting, R.K., Miller, R.D. Basics of anaesthesia, 3 rd edition. (1994) Churchill Livingstone 67-72.

Pubmed | Crossref | Others

3. Velisek, J., Wlasow, T., Gomulka, P., et al. Effects of 2-phenoxy ethanol anaesthesia on sheatfish (Silurus glanis L.). (2007) Vet Med 52(3): 103-110.

Pubmed $\mid$ Crossref $\mid$ Others

4. Soto, C.G., Burhanuddin. Clove oil as a fish anaesthetic for measuring length and weight of rabbit fish (Siganus lineatus). (1995) Aqua 136(1-2): 149-152.

Pubmed | Crossref | Others

5. Velisek, J., Svobodova, Z. Anaesthesia of common carp (Cyprinus carpio L.) with 2-phenoxy ethanol: acute toxicity and effects on biochemical blood profile. (2004) Acta Vet Brno 73(2): 247-252.

Pubmed | Crossref $\mid$ Others

6. Pirhonen, J., Schreck, C.B. Effects of anaesthesia with MS-222, clove oil and $\mathrm{CO} 2$ on feed intake and plasma cortisol in steelhead trout (Oncorhynchus mykiss). (2003) Aqua 220(1-4): 507-514.

Pubmed | Crossref | Others

7. Iwama, G.K., McGeer, J.C., Pawluk, M.P. The effects of five fish anaesthetics on acid- base balance, hematocrit, blood gases, cortisol, and adrenaline in rainbow trout. (1989) Can J Zool 67(8): 2065-2073.

Pubmed | Crossref | Others

8. Cho, G.K., Heath, D.D. Comparison of tricaine methane sulphonate (MS222) and clove oil anaesthesia effects on the physiology of juvenile Chinook salmon Oncorhynchus tshawytscha (Walbaum). (2000) Aqua Res 31(6): 537-546.

Pubmed | Crossref | Others

9. Lepic, P., Stara, A., Turek, J., et al. The effects of four anaesthetics on haematological and blood biochemical profiles in Vimba bream, Vimba vimba. (2014) Vet Med 59(2): 81-87.

Pubmed | Crossref $\mid$ Others

10. Yaghobi, M., Paykan, Heyrati, F., Dorafshan, S., et al. Serum biochemical changes and acute stress responses of the endangered iridescent cat fish (Pangasianodonhy pophthalmus) supplied with dietary nucleotide. (2015) J Agr Sci Tech 17: 1161-1170.

Pubmed | Crossref | Others

11. Houston, A.H., Dobric, N., Kahurananga, R. The nature of hematological response in fish, Studies on rainbow trout Oncorhynchus mykiss exposed to stimulated winter, spring and summer conditions. (1996) Fish Physiol Biochem 15(4): 339-347.

Pubmed | Crossref | Others

12. Rehulka, J. Influence of astaxanthin on growth rate, condition, and some blood indices of rainbow trout, Oncorhynchus mykiss. (2000) Aqua 190(1-2): 27-47.

Pubmed | Crossref | Others

13. Blaxhall, P.C., Daisley, K.W. Routine haematological methods for use with fish bloods. (1973) J Fish Biol 5(6): 771-781.

Pubmed | Crossref | Others

14. Wu, F.C., Chen, M.L., Ting, Y.Y. Hematological analysis in culture healthy mullet (Mugil cephalus). (2006) Bull Taivan Fish Cult 4: 27-36. Pubmed | Crossref | Others

15. Wedemeyer, G.A., Barton, B.A., Mcleay, D.J. Stress and acclimation. In: Schreck, CB, Moyle, PB (eds). Methods for fish biology, Bethesda, Maryland: American Fisheries Society. 1990:451-489.

Pubmed | Crossref | Others

16. Velisek, J., Wlasow, T., Gomulka, P., et al. Effects of clove oil anaesthesia on European catfish (Silurus glanis L.). (2006) Acta Vet Brno 75(1): 99-106

\section{Pubmed | Crossref | Others}

17. Sudagar, M., Mohammadi, A., Mazandarani, M., et al. The effect of clove powder as an anesthetic and its effects on hematological parameters on roach (Rutilus rutilus). (2009) J Aqua Feed Sci Nut 1(1): 1-5. Pubmed |Crossref|Others

18. Ross, L.G., Ross, B. Anaesthetic and sedative techniques for aquatic animals, Third Edition. (2008) Wiley publications 222.

Pubmed | Crossref| Others

19. Imanpoor, M.R., Bagheri, T., Hedayati, S.A. The anesthetic effects of clove essence in persian sturgeon, Acipencer persicus. (2010) World J Fish Mar Sci 2(1): 29-36.

Pubmed | Crossref | Others

20. Farahi, A., Kasiri, M., Talebi, A. Sudagar M. Effects of clove extract as an anesthetic on sperm motility traits and some hematological parameters in Crucian carp Carassius gibelio. (2011) Adv Env Biol 5: 1406-1412.

Pubmed | Crossref | Others

21. Chen, N.H. Comparison of clinical hematological changes under anesthetization in Crucian carp (Carassius auratus gibelio) following treatment with local anesthetics. (2012) Af J Biotech 11(22): 61496142 .

Pubmed | Crossref | Others

22. Wagner, G.N., Singer, T.D., Mckinley, R.S. The ability of clove oil and MS-222 to minimize handling stress in rainbow trout (Oncorhynchus mykiss Walbaum). (2003) Aqua Res 34(13): 1139-1146.

Pubmed |Crossref|Others

23. Small, B.C. Anesthetic efficacy of metomidate and comparison of plasma cortisol responses to tricaine methane sulfonate, quinaldine and clove oil anesthetized channel catfish Ictalurus punctatus. (2003) Aqua 218(1-2): 177-185.

Pubmed | Crossref| Others

24. Ackerman, P.A., Morgan, J. D., Iwama, G.K. Anesthetics. CCAC guidelines on: The care and use of fish in research, teaching and testing. Canadian Council on Animal Care, Ottawa, 2005; 22.

Pubmed |Crossref $\mid$ Others

Submit your next manuscript to Ommega Publishers and we will help you at every step:

- We accept pre-submission inquiries

- Our selector tool helps you to find the most relevant journal

- We provide round the clock customer support

- Convenient online submission

- Thorough peer review

- Inclusion in all major indexing services

- Maximum visibility for your research

Submit your manuscript at https://www.ommegaonline.org/submit-manuscript 